\title{
Both $\mathrm{GABA}_{\mathrm{B}}$ receptor activation and blockade exacerbated anhedonic aspects of nicotine withdrawal in rats
}

\author{
Styliani Vlachoua ${ }^{a}$ Neil E. Paterson ${ }^{a}, \S$, Sebastien Guery $b, \S$, Klemens Kaupmann ${ }^{b}$, \\ Wolfgang Froest $^{b}, \S$, Deboshri Banerjee ${ }^{C,}$, M.G. Finn ${ }^{\mathrm{C}}$, and Athina Markou ${ }^{a}{ }^{*}$
}

${ }^{\text {aDepartment }}$ of Psychiatry, School of Medicine, University of California San Diego, La Jolla, CA 92093-0603, USA beuroscience Research, Novartis Institutes for Biomedical Research, Novartis Pharma AG, Basel, Switzerland 'Department of Chemistry, The Scripps Research Institute, La Jolla, CA 92037, USA

Abstract

Nicotine dependence is maintained by the aversive, depression-like effects of nicotine withdrawal and the rewarding effects of acute nicotine. $\mathrm{GABA}_{\mathrm{B}}$ receptor antagonists exhibit antidepressantlike effects in rodents, whereas $\mathrm{GABA}_{\mathrm{B}}$ receptor agonists attenuate the rewarding effects of nicotine. Recent studies with $\mathrm{GABA}_{\mathrm{B}}$ receptor positive modulators showed that these compounds represent potentially improved medications for the treatment of nicotine dependence because of fewer side-effects than $\mathrm{GABA}_{\mathrm{B}}$ receptor agonists. Thus, $\mathrm{GABA}_{\mathrm{B}}$ receptor agonists and antagonists, and $\mathrm{GABA}_{\mathrm{B}}$ receptor positive modulators may have efficacy as smoking cessation aids by targeting different aspects of nicotine dependence and withdrawal. The present study assessed the effects of the $\mathrm{GABA}_{\mathrm{B}}$ receptor agonist CGP44532, the $\mathrm{GABA}_{\mathrm{B}}$ receptor antagonist CGP56433A, and the $\mathrm{GABA}_{\mathrm{B}}$ receptor positive modulator BHF177 on the anhedonic aspects of nicotine withdrawal. Rats were prepared with stimulating electrodes in the posterior lateral hypothalamus. After establishing stable intracranial self-stimulation (ICSS) thresholds, rats were prepared with subcutaneous osmotic minipumps delivering either nicotine or saline for 7 or 14 days. ICSS thresholds were assessed $6 \mathrm{~h}$ post-pump removal. Thirty hours after pump removal, CGP44532, CGP56433A, and BHF177 were administered 30 min prior to ICSS testing. Both $\mathrm{GABA}_{\mathrm{B}}$ receptor activation (CGP44532 and BHF177) and blockade (CGP56433A) elevated ICSS thresholds in all groups, resulting in exacerbated effects of nicotine withdrawal in the nicotinetreated groups. These similar effects of $\mathrm{GABA}_{\mathrm{B}}$ receptor activation and blockade on the anhedonic depression-like aspects of nicotine withdrawal were surprising and perhaps reflect differential efficacy of these compounds at presynaptic hetero- and autoreceptors, as well as postsynaptic, $\mathrm{GABA}_{\mathrm{B}}$ receptors.

(C) 2010 Elsevier B.V. All rights reserved.

"Corresponding Author: Athina Markou, Ph.D., Department of Psychiatry M/C0603, School of Medicine, University of California San Diego, 9500 Gilman Drive, La Jolla, CA 92093-0603 USA, Tel: +858-534-1572, Fax: +858-534-9917, amarkou@ucsd.edu. \$resent address:

N.E.P.: PsychoGenics, Inc., 765 Old Saw Mill River Road, Tarrytown, NY 10591, USA

S.G.: Place Marie Jose 6, 1050 Bruxelles, Belgium

W.F.: AC Immune SA, EPFL, PSE Building B 1.7, CH-1015 Lausanne, Switzerland

D.B.: Department of Medicine, Brigham and Women's Hospital, Harvard Medical School, Boston, MA 02115, USA

Publisher's Disclaimer: This is a PDF file of an unedited manuscript that has been accepted for publication. As a service to our customers we are providing this early version of the manuscript. The manuscript will undergo copyediting, typesetting, and review of the resulting proof before it is published in its final citable form. Please note that during the production process errors may be discovered which could affect the content, and all legal disclaimers that apply to the journal pertain.

Conflict of interest: The authors declare no conflicts of interest. 


\section{Keywords}

GABA; positive modulators; CGP44532; CGP56433A; BHF177; depression-like state; ICSS; brain stimulation reward

\section{Introduction}

$\gamma$-aminobutyric acid (GABA) is the main inhibitory neurotransmitter in the brain, acting through ionotropic $\mathrm{GABA}_{\mathrm{A}}$ and $\mathrm{GABA}_{\mathrm{C}}$, and metabotropic $\mathrm{GABA}_{\mathrm{B}}$ receptors. $\mathrm{GABA}_{\mathrm{B}}$ receptors are crucial in neurotransmission (Bowery et al., 2002), the pathophysiology of depression (Cryan and Slattery, 2010), and the modulation of reward processes (for review, Vlachou and Markou, 2010). Thus, $\mathrm{GABA}_{\mathrm{B}}$ receptors are a promising target for the treatment of drug, including nicotine, dependence that is characterized by alterations in reward processes [(for reviews, Buchhalter et al., 2008; Cryan et al., 2003b; Vlachou and Markou, 2010)].

Findings supporting a role of GABA transmission in nicotine dependence include observations that acute nicotine administration modulates inhibitory GABAergic and excitatory glutamatergic inputs to ventral tegmental area (VTA) dopaminergic neurons (Mansvelder et al., 2002). The VTA to the nucleus accumbens dopaminergic projection is a critical component of the neurocircuit involved in drug dependence (Di Chiara and Imperato, 1988). Thus, chronic nicotine exposure could induce neuroadaptations in $\mathrm{GABA}_{B}$ receptor number/function, in addition to changes in other neurotransmitter systems/ receptors, that could contribute to the depression-like aspects of nicotine withdrawal. The depression-like aspects of nicotine withdrawal are an important motivational factor in the perpetuation of the harmful tobacco smoking habit in humans (Hughes, 2007; Kenny and Markou, 2001).

Emerging, but contradictory, evidence from clinical and preclinical studies implicates changes in GABAergic function in the pathophysiology of non-drug-induced depression. Specifically, acute administration of $\mathrm{GABA}_{\mathrm{B}}$ receptor antagonists exhibited antidepressantlike effects in the forced swim test in rats (Frankowska et al., 2007; Slattery et al., 2005), mice and olfactory bulbectomized rats (Nowak et al., 2006). Further, repeated administration of a $\mathrm{GABA}_{\mathrm{B}}$ receptor antagonist attenuated decreases in sucrose consumption, a measure of hedonia, seen after exposure to chronic mild stress (Nowak et al., 2006), and improved learned helplessness in rats [(Nakagawa et al., 1999); but see (Sufka et al., 2009)]. Consistent with these findings, $\mathrm{GABA}_{\mathrm{B} 1}$ knockout mice displayed antidepressant-like behavior (Jacobson et al., 2007a; Jacobson and Cryan, 2005; Mombereau et al., 2004, 2005). Thus, blockade or loss of $\mathrm{GABA}_{\mathrm{B}}$ receptor function induces an antidepressant-like phenotype in rodents.

In contrast to rodent studies, clinical studies showed decreased GABA levels in plasma, cerebrospinal fluid, and cortex in depressed individuals [(Sanacora et al., 2004, 2006); for review, (Sanacora and Saricicek, 2007)], suggesting that GABA $_{B}$ receptor agonists or positive modulators, rather than antagonists, may have antidepressant properties [(Esel et al., 2008; Pilc and Nowak, 2005); but see (Nakagawa et al., 1996a,b,c; Slattery et al., 2005)]. In contradiction to the above clinical studies, $\mathrm{GABA}_{\mathrm{B}}$ receptor agonists and positive modulators exhibited antidepressant-like effects in the forced swim test in rats (Frankowska et al., 2007).

In rodents, the depression-like aspects of nicotine withdrawal are reflected in elevated intracranial self-stimulation (ICSS) reward thresholds (Epping-Jordan et al., 1998). The 
present study aimed to evaluate whether agonism or antagonism at $\mathrm{GABA}_{\mathrm{B}}$ receptors would ameliorate the depression-like aspects of nicotine withdrawal by assessing the effects of a $\mathrm{GABA}_{\mathrm{B}}$ receptor agonist, an antagonist, and a positive allosteric modulator on nicotine withdrawal-induced elevations in ICSS reward thresholds.

\section{Materials and Methods}

\subsection{Subjects}

Male Wistar rats (Charles River, Raleigh, NC) weighing 300-350 g upon arrival in the laboratory were group housed on a $12 \mathrm{~h} / 12 \mathrm{~h}$ reverse light/dark cycle with unrestricted access to water except during testing. Behavioral testing occurred during the dark phase of the light/dark cycle. All subjects, animal facilities, and experimental protocols were in accordance with National Institutes of Health (National Research Counsil, 1996) and Association for the Assessment and Accreditation of Laboratory Animal Care guidelines and were approved by the Institutional Animal Research Committee.

\subsection{Drugs}

$(-)$ Nicotine hydrogen tartrate (Sigma, St. Louis, MO) was dissolved in saline (pH adjusted to $7.0 \pm 0.5$ with sodium hydroxide). The solution was then filtered through a $0.22 \mu \mathrm{m}$ syringe filter (Fisher Scientific, Pittsburgh, PA) for sterilization. Nicotine doses are reported as free base concentrations, while all doses for $\mathrm{GABA}_{\mathrm{B}}$ receptor ligands are reported as salt concentrations. 3-amino-2[S]-hydroxypropyl)-methylphosphinic acid (CGP44532; compound \#63 in (Froestl et al., 1995), [3-\{1-(S)-[\{3(cyclohexylmethyl)hydroxylphosphinyl $\}-2-(S)$ hydroxypropyl]amino \}ethyl]benzoic acid (CGP56433A; Table IV in (Froestl et al., 1996), and $N$-[(1R,2R,4S)-bicyclo[2.2.1]hept-2yl]-2-methyl-5-[4-(trifluoromethyl)phenyl]-4-pyrimidinamine [(BHF177; compound \#27 in (Guery et al., 2007)] were synthesized and provided by SG and WF or DB and MGF. In GTPy ${ }^{35} \mathrm{~S}$ assays on CHO-K1 membranes from GABA-B $(1 \mathrm{~b} / 2)$ co-expressing cells, the potency of BHF177 was 1.7 microM (measured at 1 microM GABA; Guery et al. 2007), similar to that of other positive modulators [CGP7930 and GS39783; Urwyler et al., 2001; Urwyler et al., 2003], although BHF177 is structurally different than CGP7930 and GS39783. CGP44532 and CGP56433A were dissolved in 0.9\% saline and administered subcutaneously ( $1 \mathrm{ml} / \mathrm{kg}, 30$ min pretreatment time). BHF177 was suspended in $0.5 \%$ methylcellulose and administered intraperitoneally ( $2 \mathrm{ml} / \mathrm{kg}, 30 \mathrm{~min}$ pretreatment time). The different routes of administration used in these experiments were selected for direct comparisons with previous studies assessing the effects of $\mathrm{GABA}_{\mathrm{B}}$ receptor agonists and antagonists on performance in the ICSS task (Macey et al., 2001; Paterson et al., 2008b).

\subsection{Apparatus}

Sixteen Plexiglas chambers were used $(30.5 \times 30 \times 17 \mathrm{~cm}$; Med Associates, St. Albans, VT), each housed in a sound-attenuating box (San Diego Instruments, San Diego, CA). Each chamber contained a metal wheel manipulandum $(5 \mathrm{~cm}$ wide), centered in a side wall, that required $\sim 0.2 \mathrm{~N}$ force for a quarter turn rotation. Brain stimulation was delivered by constant current stimulators (Stimtech 1200, San Diego Instruments, San Diego, CA). Subjects were connected to the stimulation circuit with bipolar leads (Plastics One, Roanoke, VA) attached to gold-contact swivel commutators (model SL2C, Plastics One, Roanoke, VA).

\subsection{ICSS electrode placement}

Rats were anesthetized with an isoflurane/oxygen vapor mixture (1-1.5\%) and placed in a stereotaxic frame (David Kopf Instruments, Tujunga, CA). Stainless steel bipolar electrodes 
(11 mm, model MS303/2, Plastics One, Roanoke, VA) were implanted in the posterior lateral hypothalamus (anterior/posterior, $-0.5 \mathrm{~mm}$ from bregma; medial/lateral, $\pm 1.7 \mathrm{~mm}$; dorsal/ventral, $-8.3 \mathrm{~mm}$ from dura; with the incisor bar $5 \mathrm{~mm}$ above the interaural line; (Paxinos and Watson, 1998).

\subsection{Osmotic minipump implantation}

Rats were anesthetized with an isoflurane/oxygen vapor mixture (1-1.5\%), and an osmotic minipump (models 2ML1 and 2ML2, Alza Corp., Palo Alto, CA, USA) was inserted subcutaneously, as described previously (Der-Avakian and Markou, 2010; Paterson et al., 2007). Minipumps were removed on day 7 (Experiments 1 and 2) or day 14 (Experiment 3) under anesthesia.

\subsection{Behavioral procedures}

2.6.1. ICSS training-The discrete-trial current-threshold procedure was a modification of a task initially developed by Kornetsky and Esposito (1979) and described in detail elsewhere (Markou and Koob, 1992). The rats were first trained to turn the wheel manipulandum on a fixed-ratio 1 (FR1) schedule of reinforcement. Each quarter turn of the wheel resulted in the delivery of a $500 \mathrm{~ms}$ train of $0.1 \mathrm{~ms}$ cathodal square-wave pulses at a frequency of $100 \mathrm{~Hz}$. After successful acquisition of responding for stimulation on this FR1 schedule (100 reinforcements within $10 \mathrm{~min}$ ), the rats were trained gradually on the discretetrial current-threshold procedure.

Each trial began with the delivery of a noncontingent electrical stimulus, followed by a $7.5 \mathrm{~s}$ response window within which the subject could make a response to receive a second contingent stimulus identical to the initial noncontingent stimulus. A response during this time window was labeled a positive response, whereas the lack of a response was labeled a negative response. During a $2 \mathrm{~s}$ period immediately after a positive response, additional responses had no consequence. The intertrial interval that followed either a positive response or the end of the response window in the case of a negative response had an average duration of $10 \mathrm{~s}$ (ranging from $7.5 \mathrm{~s}$ to $12.5 \mathrm{~s}$ ). Responses that occurred during the intertrial interval were labeled timeout responses and resulted in a further $12.5 \mathrm{~s}$ delay of the onset of the next trial. During training on the discrete-trial procedure, the duration of the intertrial interval and delay periods induced by timeout responses were gradually increased until animals performed consistently for a fixed stimulation intensity at standard test parameters. The animals were subsequently tested on the current-intensity threshold procedure in which stimulation intensities were varied according to the classical psychophysical method of limits. A test session consisted of four alternating series of descending and ascending current intensities starting with a descending series. Blocks of three trials were presented to the subject at a given stimulation intensity, and the current intensity was changed by $5 \mu \mathrm{A}$ steps between blocks of trials. The initial stimulus intensity was set at approximately $40 \mu \mathrm{A}$ above the baseline current-intensity threshold for each animal. Each test session typically lasted 30-40 min and provided two dependent variables for behavioral assessment: threshold and response latency.

Threshold: The current-threshold for each descending series was defined as the stimulus intensity between the successful completion of a set of trials (positive responses during two or more of the three trials) and the stimulus intensity for the first set of trials, of two consecutive sets, during which the animal failed to respond positively on two or more of the three trials. The current-intensity threshold for each ascending series was defined as the stimulus intensity between a current intensity in which the animal failed to respond positively on two or more of the three trials and the first set of trials, of two consecutive sets, 
during which the animal responded positively on two or more of the three trials. The mean of the four series' thresholds was defined as the threshold for the session.

Response latency: The time interval between the beginning of the noncontingent stimulus and a positive response was recorded as the response latency. The response latency for each session was defined as the mean response latency on all trials during which a positive response occurred.

\subsubsection{Experimental procedures}

Experiment 1. Effects of the GABA ${ }_{B}$ receptor agonist CGP44532 on nicotine withdrawal assessed by ICSS threshold elevations: After successful acquisition of stable ICSS thresholds (less than 10\% variation over 3 baseline days), naive rats were prepared with minipumps containing either nicotine or saline $(3.16 \mathrm{mg} / \mathrm{kg} /$ day nicotine base). Seven days later, pumps were removed under anesthesia, and ICSS thresholds were assessed $6 \mathrm{~h}$ later and at $24 \mathrm{~h}$ intervals thereafter. Rats were assigned to six groups ( $n=9-11 /$ group), counter-balanced for ICSS threshold elevations (for the three nicotine-treated groups) at the $6 \mathrm{~h}$ post-pump time-point (three dose groups per pump content [nicotine or saline]). CGP44532 (0, 0.25, and $0.5 \mathrm{mg} / \mathrm{kg}$, s.c.) was administered according to a between-subjects design $30 \mathrm{~min}$ prior to ICSS testing at the $30 \mathrm{~h}$ post-pump time-point. Thresholds continued to be assessed at $24 \mathrm{~h}$ intervals until thresholds returned to pre-nicotine/saline baseline levels.

Experiment 2. Effects of the GABA $\underline{B}$ receptor antagonist CGP56433A on nicotine withdrawal assessed by ICSS threshold elevations: The experimental design of this study was identical to that of Experiment 1 described above. CGP56433A (0,5, and $10 \mathrm{mg} / \mathrm{kg}$, s.c.) was administered according to a between-subjects design. Thus, similar to Experiment 1, Experiment 2 had six groups, with 8-10 rats/group.

Experiment 3. Effects of the GABA $\underline{B}$ receptor positive modulator BHF177 on nicotine withdrawal assessed by ICSS threshold elevations: The experimental design of this study was identical to that of Experiments 1 and 2 described above, except that BHF177 (0, 7.5, and $15 \mathrm{mg} / \mathrm{kg}$, i.p.) was administered according to a between-subjects design, and rats were exposed to nicotine/saline for 14 instead of 7 days. Similar to Experiments 1 and 2, Experiment 3 had six groups, with 8-11 rats/group. The longer nicotine exposure was intended to induce a more prolonged or larger magnitude of threshold elevations than the one seen in Experiments 1 and 2 (Skjei and Markou, 2003).

\subsection{Data analyses}

Data are expressed as a percentage of the mean of the three baseline values before the implantation of the minipumps (i.e., to assess the effects during the nicotine administration phase). To most accurately represent the withdrawal effects and the effects of manipulations, we expressed the nicotine withdrawal phase data as a percentage of the baseline values obtained on the last day before pump removal. Data were analyzed using appropriate twoway mixed-factor analyses of variance (ANOVAs). Significant main or interaction effects were followed by one- or two-way ANOVAs on data from specific time-points post-pump removal and Newman-Keuls post hoc tests. Values of $P<0.05$ were considered statistically significant. Statistical analyses were conducted using the Statistical Package for the Social Sciences v.16.0 and GraphPad Prism 6.0. 


\section{Results}

\subsection{Experiment 1: Effects of the GABA $A_{B}$ receptor agonist CGP44532 on nicotine withdrawal}

3.1.1. Nicotine administration phase-In nicotine-exposed rats, mean ( \pm SEM) baseline ICSS thresholds and latencies were $96.7 \pm 2.9 \mu \mathrm{A}$ and $3.2 \pm 0.1 \mathrm{~s}$, respectively. In saline-exposed rats, mean ( \pm SEM) thresholds and latencies were $97.6 \pm 4.4 \mu \mathrm{A}$ and $3.3 \pm$ $0.1 \mathrm{~s}$, respectively. Administration of nicotine or saline via osmotic minipumps did not affect ICSS thresholds, whereas response latencies were shorter during the 7 days of exposure (Nicotine: $F_{1,49}=4.89, P<0.05$ ). No significant interaction effects were observed on thresholds or response latencies.

3.1.2. Nicotine withdrawal phase-A two-way repeated measures ANOVA on ICSS thresholds obtained during the 5 days after minipump removal (Pump: two levels; CGP44532 Dose: three levels) indicated that nicotine withdrawal was associated with significantly elevated ICSS thresholds ( $P$ ump: $F_{1,57}=22.92, P<0.0001$ ) that returned to baseline values over the 5 days of testing (Time: $F_{4,172}=25.83, P<0.0001$; Pump $\times$ Time: $\left.F_{4,172}=9.91, P<0.0001\right)$. A follow-up one-way ANOVA on data at the $6 \mathrm{~h}$ post-pump removal time-point indicated that all nicotine-treated groups exhibited significantly elevated thresholds compared with rats exposed to saline-containing minipumps (main effect of Pump: $F_{1,53}=39.09, P<0.001$ ). A follow-up two-way ANOVA on data from the $30 \mathrm{~h}$ postpump removal time-point showed that administration of CGP44532 elevated ICSS thresholds in all groups (CGP44532 Dose: $\left.F_{2,54}=7.73, P<0.05\right)$, and a significant difference was also observed between the saline- and nicotine-exposed rats at the same timepoint (main effect of Pump: $F_{1,53}=31.38, P<0.0001$ ). No Pump $\times$ CGP44532 Dose interaction was observed, indicating that the effects of CGP44532 were independent of whether rats were previously exposed to nicotine or saline. Post hoc comparisons indicated that nicotine-treated rats receiving 0.25 and $0.5 \mathrm{mg} / \mathrm{kg}$ CGP44532 exhibited significantly elevated ICSS thresholds compared with the saline $/ 0 \mathrm{mg} / \mathrm{kg}$ CGP44532-treated control group $(P<0.001$ and $P<0.01$, respectively), saline/0.25 mg CGP44532 group $(P<0.01)$, and saline/ $0.5 \mathrm{mg}$ CGP44532 group at the $30 \mathrm{~h}$ time-point $(P<0.01$ and $P<0.05$, respectively), respectively; Fig. 1). Nicotine-exposed rats receiving $0.25 \mathrm{mg} / \mathrm{kg}$ CGP44532 showed elevated ICSS thresholds compared with saline-exposed rats receiving $0.25 \mathrm{mg} / \mathrm{kg}$ CGP44532 at $54 \mathrm{~h}$ and $78 \mathrm{~h}$ after pump removal $(P<0.001, P<0.05$, respectively). Analysis of the response latency data indicated no effects of any of the manipulations on response latencies (data not shown).

\subsection{Experiment 2: Effects of the GABA $\mathrm{G}_{B}$ receptor antagonist CGP56433A on nicotine withdrawal}

3.2.1. Nicotine administration phase-In nicotine-exposed rats, mean ( \pm SEM) baseline thresholds and latencies were $106.5 \pm 5.3 \mu \mathrm{A}$ and $3.2 \pm 0.1 \mathrm{~s}$, respectively. In saline-exposed rats, mean $( \pm$ SEM) baseline thresholds and latencies were $102.5 \pm 6.7 \mu \mathrm{A}$ and $3.0 \pm 0.1 \mathrm{~s}$, respectively. Administration of nicotine or saline via minipumps did not affect ICSS thresholds or response latencies. Only a gradual small decrease in thresholds was observed in both the saline and nicotine groups over the 7 days of saline or nicotine exposure (main effect of Time: $F_{6,53}=2.22, P<0.05$ ).

3.2.2. Nicotine withdrawal phase-A two-way repeated-measures ANOVA (Pump: two levels; CGP56433A Dose: three levels) on the threshold data obtained during the 5 days after minipump removal indicated that nicotine withdrawal was associated with significantly elevated ICSS thresholds (Pump: $F_{1,52}=6.50, P<0.05$ ) that returned to baseline levels over the 5 days of testing (Time: $F_{4,208}=20.91, P<0.0001 ;$ Pump $\times$ Time: $F_{4,208}=5.25, P<$ 
0.001). A follow-up one-way ANOVA on data from the $6 \mathrm{~h}$ post-pump removal time-point indicated that nicotine-treated rats exhibited significantly elevated thresholds compared with saline-treated rats (main effect of Pump: $F_{1,48}=28.11, P<0.0001$ ). A follow-up two-way ANOVA on data from the $30 \mathrm{~h}$ post-pump removal time-point showed that administration of CGP56433A elevated ICSS thresholds in all groups (CGP56433A Dose: $F_{2,48}=8.92, P<$ 0.001 ), and a significant difference was also observed between the saline- and nicotinetreated rats (main effect of Pump: $F_{1,48}=7.26, P<0.01$ ). No significant Pump $\times$ CGP56433A Dose interaction effect was observed, indicating that the effects of CGP56433A were independent of whether rats were previously exposed to nicotine or saline. Post hoc comparisons revealed that ICSS thresholds in nicotine-exposed subjects receiving $10 \mathrm{mg} / \mathrm{kg}$ CGP56433A were significantly elevated compared with thresholds in saline- and nicotine $/ 0 \mathrm{mg} / \mathrm{kg}$ CGP56433A rats $(P<0.001)$, saline $/ 5 \mathrm{mg} / \mathrm{kg}$ CGP56433A rats $(P<0.01)$, saline/10 $\mathrm{mg}$ CGP56433A rats $(P<0.01)$, and nicotine/5 $\mathrm{mg}$ CGP56433A rats $(P<0.05)$ at the $30 \mathrm{~h}$ time-point (Fig. 2). No effects of any of the manipulations were observed on response latencies (data not shown).

\subsection{Experiment 3: Effects of the $\mathrm{GABA}_{B}$ receptor positive modulator BHF177 on nicotine withdrawal}

3.3.1. Nicotine administration phase-In nicotine-exposed rats, mean ( \pm SEM) baseline thresholds and latencies were $97.4 \pm 4.9 \mu \mathrm{A}$ and $3.0 \pm 0.1 \mathrm{~s}$, respectively. In salineexposed rats, mean $( \pm$ SEM) baseline thresholds and latencies were $93.5 \pm 7.6 \mu \mathrm{A}$ and $3.1 \pm$ $0.2 \mathrm{~s}$, respectively. Administration of nicotine or saline via minipumps for 14 days did not affect ICSS thresholds. Response latencies were shorter (main effect of Time: $F_{13,49}=$ $4.068, P<0.001)$ during the 14 days of pump exposure, regardless of pump content.

3.3.2. Nicotine withdrawal phase-A two-way ANOVA on ICSS thresholds obtained during the 5 days after minipump removal (Pump: two levels; BHF177 Dose: three levels) indicated that nicotine withdrawal was associated with significantly elevated ICSS thresholds (Pump: $F_{1,49}=10.64, P<0.01$ ) that returned to baseline levels over the 5 days of testing (Time: $F_{4,196}=12.55, P<0.0001 ;$ Pump $\times$ Time: $F_{4,196}=6.81, P<0.0001$ ). A follow-up one-way ANOVA on the $6 \mathrm{~h}$ post-pump removal time-point data showed that nicotine withdrawal significantly elevated ICSS thresholds compared with saline "withdrawal" $\left(F_{1,45}=20.00, P<0.0001\right)$. A follow-up two-way ANOVA on data from the $30 \mathrm{~h}$ post-pump removal time-point showed that nicotine withdrawal continued to elevate thresholds at this time-point (main effect of Pump: $F_{1,45}=8.84, P<0.01$ ). Administration of BHF177 at the $30 \mathrm{~h}$ time-point exacerbated the already elevated ICSS thresholds induced by nicotine withdrawal (BHF177 Dose: $F_{2,45}=4.03, P<0.05$ ). Post hoc comparisons indicated that ICSS thresholds in nicotine-exposed subjects receiving $15 \mathrm{mg}$ BHF177 were significantly greater than in the saline $/ 0 \mathrm{mg} / \mathrm{kg}$ BHF177-treated group at the $30 \mathrm{~h}$ time-point post-pump removal $(P<0.05 ;$ Fig. 3$)$. Analysis of response latency data indicated that response latencies were not affected by any of the manipulations (data not shown).

\section{Discussion}

The present studies showed that administration of a $\mathrm{GABA}_{\mathrm{B}}$ receptor agonist, antagonist, or positive allosteric modulator exacerbated the elevated ICSS thresholds observed during nicotine withdrawal in rats. These threshold elevations during nicotine withdrawal are hypothesized to reflect an anhedonic state, and are consistent with results from previous studies in rodents (Epping-Jordan et al., 1998; Harrison et al., 2001; Johnson et al., 2008; Paterson et al., 2008a; Rylkova et al., 2008; Stoker et al., 2008). Both doses of the GABA receptor agonist CGP44532 (0.25 and $0.5 \mathrm{mg} / \mathrm{kg})$, and the highest doses of either the $\mathrm{GABA}_{\mathrm{B}}$ receptor antagonist CGP56433A $(10 \mathrm{mg} / \mathrm{kg})$ or the $\mathrm{GABA}_{\mathrm{B}}$ receptor positive 
modulator BHF177 (15 mg/kg) exacerbated the elevated ICSS thresholds seen during nicotine withdrawal. The effects of CGP56433A and BHF177 in nicotine-treated rats were short-lived, but ICSS thresholds remained elevated in nicotine-, but not saline-, exposed rats that received $0.25 \mathrm{mg} / \mathrm{kg}$ CGP44532, 24-48 $\mathrm{h}$ after CGP44532 administration (54-78 h post-nicotine). Thus, all GABA $\mathrm{B}_{\mathrm{B}}$ receptor ligands elevated ICSS reward thresholds in both nicotine- and saline-exposed rats, as reflected by the lack of a statistically significant interaction between nicotine/saline exposure and GABA compound dose.

It is possible that the results are due to a variety of non-specific effects of the compounds. However, administration of doses of CGP44532, CGP56433A or BHF177 that significantly exacerbated the elevated ICSS thresholds seen during nicotine withdrawal did not affect the animals' performance, as reflected in lack of effects on response latencies. This lack of nonspecific effects is consistent with previous findings showing lack of effects of $\mathrm{GABA}_{B}$ compounds on response latencies in the ICSS procedure under baseline conditions or during nicotine-induced facilitation of brain reward function (Macey et al., 2001; Paterson et al., 2008b), These findings indicate that there were no sedative or muscle relaxant effects of the compounds that could have interfered with task performance.

One could also speculate that the nicotine withdrawal/ICSS model of anhedonia is not suitable for detecting the effects of GABA compounds. However, this possibility is rather unlikely, because this model has been shown to reliably detect antidepressant-like properties of a variety of compounds, such as selective serotonin reuptake inhibitors (Harrison et al. 2001), the tricyclic antidepressant desipramine (Paterson et al 2008a), the atypical antidepressant bupropion (Cryan et al., 2003a; Paterson 2007), as well as the effects of novel compounds that have not been shown yet to have antidepressant properties in humans, such as a Group II metabotropic glutamate receptor antagonist (Kenny et al., 2003), and an alpha2 adrenergic receptor antagonist (Semenova and Markou, 2010). Thus, nicotine-induced elevations in brain reward thresholds is an animal model of depression-like behavior that is sensitive to the effects of a variety of antidepressant or putative antidepressant treatments that act through various neurotransmitter systems and targets.

The similar behavioral effects of the $\mathrm{GABA}_{\mathrm{B}}$ receptor agonists, antagonists and positive modulators on the depressive-like aspect of nicotine withdrawal are unexpected.

Nevertheless, many other studies have also reported similar effects of $\mathrm{GABA}_{\mathrm{B}}$ agonists and antagonists. Specifically, both the $\mathrm{GABA}_{B}$ receptor agonist CGP44532 and the $\mathrm{GABA}_{B}$ receptor antagonist CGP56433A elevated ICSS thresholds in rats under baseline conditions (Macey et al., 2001). Furthermore, the GABA $\mathrm{B}_{\mathrm{B}}$ receptor positive modulator CGP7930 and the $\mathrm{GABA}_{\mathrm{B}}$ receptor antagonist $\mathrm{SCH} 50911$ showed antidepressant-like profiles in the forced swim test in mice, similar to the GABA $A_{B}$ receptor agonists baclofen and SKF 97541 (also termed CGP35024; (Chebib et al., 1997), which also exhibits GABA $_{C}$ receptor antagonist properties (Frankowska et al., 2007). $\mathrm{GABA}_{\mathrm{B}}$ receptor positive modulators and antagonists also exhibited similar effects in the elevated zero maze, while neither of them was effective in the modified Geller-Seifter task, both tests of anxiety-like behavior (Frankowska et al., 2007; but see Paterson and Hanania, 2010).

Furthermore, both the $\mathrm{GABA}_{\mathrm{B}}$ receptor agonist baclofen and the $\mathrm{GABA}_{\mathrm{B}}$ receptor antagonist CGP35348 reduced the acquisition and expression of morphine-induced conditioned place preference in morphine-sensitized animals (Sahraei et al., 2009). Additionally, $\mathrm{GABA}_{\mathrm{B}}$ receptor agonists and antagonists exhibited similar behavioral effects in tests of cognitive function, such as passive avoidance, a fear-motivated avoidance task that assesses memory (Castellano et al., 1993; Escher and Mittleman, 2004; Mondadori et al., 1993). Despite impaired performance in a spatial working memory task exhibited by $\mathrm{GABA}_{\mathrm{B}}$ receptor knockout mice (Jacobson et al., 2007b), GABA $\mathrm{B}$ receptor antagonists 
improved working memory, reflected by improved pattern recognition speed and attention, reflected by choice reaction time and visual information processing, in humans (Froestl et al., 2004), as well as performance in learning and memory tasks (Getova and Bowery, 1998; Helm et al., 2005; Nakagawa and Takashima, 1997) in rodents and non-human primates.

Altogether, these findings indicate that opposing actions of $\mathrm{GABA}_{\mathrm{B}}$ receptor agonists and antagonists had effects in the same direction in various behavioral studies, including antidepressant-like and anxiolytic-like properties, exacerbation of the depressive-like state of nicotine withdrawal, decreased brain stimulation and morphine reward, and improved performance in cognitive tasks.

Based on the above findings, it is likely that $\mathrm{GABA}_{\mathrm{B}}$ receptor agonists, antagonists and modulators induce the same direction of effects by differentially binding to the various $\mathrm{GABA}_{\mathrm{B}}$ receptors. Specifically, $\mathrm{GABA}_{\mathrm{B}}$ receptors are high-molecular-mass complexes, consisting of two main subunits, $\mathrm{GABA}_{\mathrm{B} 1}$ and $\mathrm{GABA}_{\mathrm{B} 2}$, and auxiliary subunits, such as potassium channel tetramerization domain-containing (KCTD) proteins (Bartoi et al., 2010). KCTD proteins associate tightly with the carboxy terminus of the $\mathrm{GABA}_{\mathrm{B} 2}$ subunit as tetramers, thus increasing agonist potency and altering G-protein signaling by accelerating signaling onset and promoting receptor desensitization (Schwenk et al., 2010). The GABA receptor isoforms $\mathrm{GABA}_{\mathrm{B} 1 \mathrm{a}}$ and $\mathrm{GABA}_{\mathrm{B} 1 \mathrm{~b}}$ (Kaupmann et al., 1997) combine with the $\mathrm{GABA}_{\mathrm{B} 2}$ subunit to form a functional receptor (Jones et al., 1998; Kaupmann et al., 1998; Kuner et al., 1999; Mohler and Fritschy, 1999; Ng et al., 1999; White et al., 1998). The $\mathrm{GABA}_{\mathrm{B} 1 \mathrm{a} / 2}$ isoform is mainly found presynaptically as a heteroreceptor that regulates glutamate, dopamine, and serotonin transmission (Vigot et al., 2006), whereas the $\mathrm{GABA}_{\mathrm{B} 1 \mathrm{~b} / 2}$ isoform is located primarily postsynaptically. Both $\mathrm{GABA}_{\mathrm{B} 1 \mathrm{a} / 2}$ and $\mathrm{GABA}_{\mathrm{B} 1 \mathrm{~b} / 2}$ isoforms are also presynaptic autoreceptors that inhibit neurotransmitter release through inhibition of $\mathrm{Ca}^{2+}$ channels. Importantly, both pre- and postsynaptic $\mathrm{GABA}_{\mathrm{B}}$ receptors are expressed in brain reward circuitries and are hypothesized to be involved in reward processes (e.g. Bischoff et al., 1999; Brebner et al., 1999; Corrigall et al., 2000; Fattore et al., 2002; Frankowska et al., 2008; Paterson et al., 2004; Xi et al., 2003).

Based on the localization of the different $\mathrm{GABA}_{\mathrm{B}}$ receptor subtypes (Bettler and Tiao, 2006; Vigot et al., 2006), it is possible that the results are due to differential binding of the $\mathrm{GABA}_{\mathrm{B}}$ receptor ligands on these receptor subtypes. For example, the $\mathrm{GABA}_{\mathrm{B}}$ receptor agonist CGP44532 may have further increased the hypothesized increased GABAergic neurotransmitter function associated with nicotine withdrawal by possibly activating postsynaptic $\mathrm{GABA}_{\mathrm{B} 1 \mathrm{~b} / 2}$ receptors. The $\mathrm{GABA}_{\mathrm{B}}$ receptor positive modulator BHF177 may have acted similarly, by binding to the $\mathrm{GABA}_{\mathrm{B} 2}$ subunit of the $\mathrm{GABA}_{\mathrm{B}}$ receptor (Binet et al., 2004; Cryan and Kaupmann, 2005; Dupuis et al., 2006) at postsynaptic sites. By contrast, the $\mathrm{GABA}_{\mathrm{B}}$ receptor antagonist CGP56433A is hypothesized to have acted by blocking primarily presynaptic autoreceptors of either the $\mathrm{GABA}_{\mathrm{B} 1 \mathrm{a} / 2}$ or $\mathrm{GABA}_{\mathrm{B} 1 \mathrm{~b} / 2}$ isoform on GABAergic terminals, thus further increasing GABA release during nicotine withdrawal. Importantly, based on the recently demonstrated heterogeneity of $\mathrm{GABA}_{B}$ receptors and their multi-subunit structure, the effects of the tested $\mathrm{GABA}_{\mathrm{B}}$ receptor compounds on $\mathrm{GABA}_{\mathrm{B}}$ receptors could also be affected by the effects of KCTD auxiliary subunits on the $\mathrm{GABA}_{\mathrm{B} 2}$ receptor subunit (Bartoi et al., 2010; Schwenk et al., 2010). Several behavioral effects summarized above, showing that opposing actions of $\mathrm{GABA}_{B}$ receptor agonists, antagonists and modulators had effects in the same direction, support this speculative hypothesis of differential binding of the $\mathrm{GABA}_{\mathrm{B}}$ receptor ligands on the different $\mathrm{GABA}_{B}$ receptor subtypes (e.g. Frankowska et al., 2007; Macey et al., 2001). 


\section{Conclusions}

In summary, both $\mathrm{GABA}_{\mathrm{B}}$ receptor activation and blockade aggravated the anhedonic state of nicotine withdrawal in rats. Thus, these compounds did not exhibit antidepressant-like effects in the nicotine withdrawal/ICSS model of anhedonia (Barr and Markou, 2005) and, therefore, may not be useful therapeutics for the treatment of the depression-like state and anhedonia associated with nicotine withdrawal.

None of the compounds used in the present studies are known to be selective for specific $\mathrm{GABA}_{\mathrm{B}}$ receptor isoforms or for pre- $v s$. postsynaptic $\mathrm{GABA}_{\mathrm{B}}$ receptors. The unidirectional effects of $G_{A B A}$ receptor activation and blockade may reflect differential efficacy of these compounds at presynaptic hetero- and autoreceptors compared with postsynaptic $\mathrm{GABA}_{\mathrm{B}}$ receptors. The development of more selective $\mathrm{GABA}_{\mathrm{B}}$ receptor subtype ligands will allow the delineation of the role of these $\mathrm{GABA}_{\mathrm{B}}$ receptor isoforms in reward-related processes and in the anhedonic aspects of nicotine withdrawal and depression.

\section{Acknowledgments}

This work was supported by National Institutes of Health grant U19DA026838 to AM. SV was supported by an Individual Postdoctoral Research Fellowship from the Tobacco-Related Disease Research Program from the State of California (18FT-0048). The authors wish to thank Mr. Michael Arends for editorial support, and Mrs. Kim Edwards and Mrs. Jessica Benedict for technical assistance.

\section{References}

Barr AM, Markou A. Psychostimulant withdrawal as an inducing condition in animal models of depression. Neurosci. Biobehav. Rev. 2005; 29:675-706. [PubMed: 15893821]

Bartoi T, Rigbolt KT, Du D, Kohr G, Blagoev B, Kornau HC. GABA B receptor constituents revealed by tandem affinity purification from transgenic mice. J. Biol. Chem. 2010; 285:20625-20633. [PubMed: 20406808]

Bettler B, Tiao JY. Molecular diversity, trafficking and subcellular localization of $\mathrm{GABA}_{\mathrm{B}}$ receptors. Pharmacol. Ther. 2006; 110:533-543. [PubMed: 16644017]

Binet V, Brajon C, Le Corre L, Archer F, Pin JP, Prezeau L. The heptahelical domain of GABA $\mathrm{B} 2$ is activated directly by CGP7930, a positive allosteric modulator of the $\mathrm{GABA}_{\mathrm{B}}$ receptor. J. Biol. Chem. 2004; 279:29085-29091. [PubMed: 15126507]

Bischoff S, Leonhard S, Reymann N, Schuler V, Shigemoto R, Kaupmann K, Bettler B. Spatial distribution of $\mathrm{GABA}_{\mathrm{B}} \mathrm{R} 1$ receptor mRNA and binding sites in the rat brain. J. Comp. Neurol. 1999; 412:1-16. [PubMed: 10440706]

Bowery NG, Bettler B, Froestl W, Gallagher JP, Marschall F, Raiteri M, Bonner TI, Enna SJ. International Union of Pharmacology. XXXIII. Mammalian $\gamma$-aminobutyric acid $_{\mathrm{B}}$ receptors: structure and function. Pharmacol. Rev. 2002; 54:247-264. [PubMed: 12037141]

Brebner K, Froestl W, Andrews M, Phelan R, Roberts DC. The GABAB agonist CGP44532 decreases cocaine self-administration in rats: demonstration using a progressive ratio and a discrete trials procedure. Neuropharmacology. 1999; 38:1797-1804. [PubMed: 10587095]

Buchhalter AR, Fant RV, Henningfield JE. Novel pharmacological approaches for treating tobacco dependence and withdrawal: current status. Drugs. 2008; 68:1067-1088. [PubMed: 18484799]

Castellano C, Cestari V, Cabib S, Puglisi-Allegra S. Strain-dependent effects of post-training GABA receptor agonists and antagonists on memory storage in mice. Psychopharmacology (Berl). 1993; 111:134-138. [PubMed: 7870943]

Chebib M, Vandenberg RJ, Froestl W, Johnston GA. Unsaturated phosphinic analogues of $\gamma$ aminobutyric acid as GABA ${ }_{C}$ receptor antagonists. Eur. J. Pharmacol. 1997; 329:223-229. [PubMed: 9226416]

Corrigall WA, Coen KM, Adamson KL, Chow BL, Zhang J. Response of nicotine self-administration in the rat to manipulations of mu-opioid and $\gamma$-aminobutyric acid receptors in the ventral tegmental area. Psychopharmacology (Berl). 2000; 149:107-114. [PubMed: 10805604] 
Cryan JF, Bruijnzeel AW, Skjei KL, Markou A. Bupropion enhances brain reward function and reverses the affective and somatic aspects of nicotine withdrawal in the rat. Psychopharmacology. 2003a; 168:347-358. [PubMed: 12698231]

Cryan JF, Gasparini F, van Heeke G, Markou A. Non-nicotinic neuropharmacological strategies for nicotine dependence: beyond bupropion. Drug Discov. Today. 2003b; 8:1025-1034. [PubMed: 14690633]

Cryan JF, Kaupmann K. Don't worry 'B' happy!: a role for $\mathrm{GABA}_{\mathrm{B}}$ receptors in anxiety and depression. Trends Pharmacol. Sci. 2005; 26:36-43. [PubMed: 15629203]

Cryan JF, Slattery DA. GABA B receptors and depression: current status. Adv. Pharmacol. 2010; 58:427-451. [PubMed: 20655491]

Der-Avakian A, Markou A. Withdrawal from chronic exposure to amphetamine, but not nicotine, leads to an immediate and enduring deficit in motivated behavior without affecting social interaction in rats. Behav. Pharmacol. 2010; 21:359-368. [PubMed: 20571366]

Di Chiara G, Imperato A. Drugs abused by humans preferentially increase synaptic dopamine concentrations in the mesolimbic system of freely moving rats. Proc. Natl. Acad. Sci. U S A. 1988; 85:5274-5278. [PubMed: 2899326]

Dupuis DS, Relkovic D, Lhuillier L, Mosbacher J, Kaupmann K. Point mutations in the transmembrane region of $\mathrm{GABA}_{\mathrm{B} 2}$ facilitate activation by the positive modulator $N, N$ dicyclopentyl-2-methylsulfanyl-5-nitro-pyrimidine-4,6-diamine (GS39783) in the absence of the GABA $_{B 1}$ subunit. Mol. Pharmacol. 2006; 70:2027-2036. [PubMed: 16966477]

Epping-Jordan MP, Watkins SS, Koob GF, Markou A. Dramatic decreases in brain reward function during nicotine withdrawal. Nature. 1998; 393:76-79. [PubMed: 9590692]

Escher T, Mittleman G. Effects of ethanol and GABA $\mathrm{B}$ drugs on working memory in C57BL/6J and DBA/2J mice. Psychopharmacology (Berl). 2004; 176:166-174. [PubMed: 15064920]

Esel E, Kose K, Hacimusalar Y, Ozsoy S, Kula M, Candan Z, Turan T. The effects of electroconvulsive therapy on GABAergic function in major depressive patients. J. ECT. 2008; 24:224-228. [PubMed: 18562944]

Fattore L, Cossu G, Martellotta MC, Fratta W. Baclofen antagonizes intravenous self-administration of nicotine in mice and rats. Alcohol Alcohol. 2002; 37:495-498. [PubMed: 12217945]

Frankowska M, Filip M, Przegalinski E. Effects of GABA $_{B}$ receptor ligands in animal tests of depression and anxiety. Pharmacol. Rep. 2007; 59:645-655. [PubMed: 18195453]

Frankowska M, Wydra K, Faron-Gorecka A, Zaniewska M, Kusmider M, Dziedzicka-Wasylewska M, Filip M. Neuroadaptive changes in the rat brain $\mathrm{GABA}_{\mathrm{B}}$ receptors after withdrawal from cocaine self-administration. Eur. J. Pharmacol. 2008; 599:58-64. [PubMed: 18848829]

Froestl W, Gallagher M, Jenkins H, Madrid A, Melcher T, Teichman S, Mondadori CG, Pearlman R. SGS742: the first $\mathrm{GABA}_{\mathrm{B}}$ receptor antagonist in clinical trials. Biochem. Pharmacol. 2004; 68:1479-1487. [PubMed: 15451390]

Froestl W, Mickel SJ, Hall RG, von Sprecher G, Strub D, Baumann PA, Brugger F, Gentsch C, Jaekel J, Olpe HR, Rihs G, Vassout A, Waldmeier PC, Bittiger H. Phosphinic acid analogues of GABA.

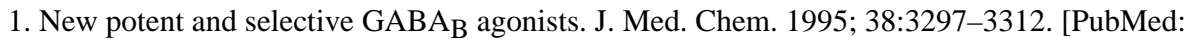
7650684]

Froestl W, Mickel SJ, Schmutz M, Bittiger H. Potent, orally active GABA $\mathrm{B}$ receptor antagonists. Pharmacol. Rev. Commun. 1996; 8:127-133.

Getova D, Bowery NG. The modulatory effects of high affinity $\mathrm{GABA}_{\mathrm{B}}$ receptor antagonists in an active avoidance learning paradigm in rats. Psychopharmacology (Berl). 1998; 137:369-373. [PubMed: 9676897]

Guery S, Floersheim P, Kaupmann K, Froestl W. Syntheses and optimization of new GS39783 analogues as positive allosteric modulators of $\mathrm{GABA}_{\mathrm{B}}$ receptors. Bioorg. Med. Chem. Lett. 2007; 17:6206-6211. [PubMed: 17884493]

Harrison AA, Liem YT, Markou A. Fluoxetine combined with a serotonin-1A receptor antagonist reversed reward deficits observed during nicotine and amphetamine withdrawal in rats. Neuropsychopharmacology. 2001; 25:55-71. [PubMed: 11377919]

Helm KA, Haberman RP, Dean SL, Hoyt EC, Melcher T, Lund PK, Gallagher M. GABA B receptor antagonist SGS742 improves spatial memory and reduces protein binding to the cAMP response 
element (CRE) in the hippocampus. Neuropharmacology. 2005; 48:956-964. [PubMed: 15857622]

Hughes JR. Effects of abstinence from tobacco: etiology, animal models, epidemiology, and significance: a subjective review. Nicotine Tob. Res. 2007; 9:329-339. [PubMed: 17365765]

Jacobson LH, Bettler B, Kaupmann K, Cryan JF. Behavioral evaluation of mice deficient in GABA 1 receptor isoforms in tests of unconditioned anxiety. Psychopharmacology (Berl). 2007a; 190:541553. [PubMed: 17171558]

Jacobson LH, Cryan JF. Differential sensitivity to the motor and hypothermic effects of the GABA receptor agonist baclofen in various mouse strains. Psychopharmacology (Berl). 2005; 179:688699. [PubMed: 15668819]

Jacobson LH, Kelly PH, Bettler B, Kaupmann K, Cryan JF. Specific roles of GABAB1 receptor isoforms in cognition. Behav. Brain Res. 2007b; 181:158-162. [PubMed: 17498817]

Johnson PM, Hollander JA, Kenny PJ. Decreased brain reward function during nicotine withdrawal in C57BL6 mice: evidence from intracranial self-stimulation (ICSS) studies. Pharmacol. Biochem. Behav. 2008; 90:409-415. [PubMed: 18466962]

Jones KA, Borowsky B, Tamm JA, Craig DA, Durkin MM, Dai M, Yao WJ, Johnson M, Gunwaldsen C, Huang LY, Tang C, Shen Q, Salon JA, Morse K, Laz T, Smith KE, Nagarathnam D, Noble SA, Branchek TA, Gerald C. GABA $\mathrm{B}$ receptors function as a heteromeric assembly of the subunits GABA $_{B} R 1$ and $G_{A B A} R 2$. Nature. 1998; 396:674-679. [PubMed: 9872315]

Kaupmann K, Huggel K, Heid J, Flor PJ, Bischoff S, Mickel SJ, McMaster G, Angst C, Bittiger H, Froestl W, Bettler B. Expression cloning of $\mathrm{GABA}_{\mathrm{B}}$ receptors uncovers similarity to metabotropic glutamate receptors. Nature. 1997; 386:683-687.

Kaupmann K, Malitschek B, Schuler V, Heid J, Froestl W, Beck P, Mosbacher J, Bischoff S, Kulik A, Shigemoto R, Karschin A, Bettler B. GABA ${ }_{B}$-receptor subtypes assemble into functional heteromeric complexes. Nature. 1998; 396:683-687. [PubMed: 9872317]

Kenny PJ, Gasparini F, Markou A. Group II metabotropic and alpha-amino-3-hydroxy-5-methyl-4isoxazole propionate (AMPA)/kainate glutamate receptors regulate the deficit in brain reward function associated with nicotine withdrawal in rats. J. Pharmacol. Exp. Ther. 2003; 306:10681076. [PubMed: 12805481]

Kenny PJ, Markou A. Neurobiology of the nicotine withdrawal syndrome. Pharmacol. Biochem. Behav. 2001; 70:531-549. [PubMed: 11796152]

Kornetsky C, Esposito RU. Euphorigenic drugs: effects on the reward pathways of the brain. Fed. Proc. 1979; 38:2473-2476. [PubMed: 488370]

Kuner R, Kohr G, Grunewald S, Eisenhardt G, Bach A, Kornau HC. Role of heteromer formation in GABA $_{B}$ receptor function. Science. 1999; 283:74-77. [PubMed: 9872744]

Macey DJ, Froestl W, Koob GF, Markou A. Both GABAB receptor agonist and antagonists decreased brain stimulation reward in the rat. Neuropharmacology. 2001; 40:676-685. [PubMed: 11311895]

Mansvelder HD, Keath JR, McGehee DS. Synaptic mechanisms underlie nicotine-induced excitability of brain reward areas. Neuron. 2002; 33:905-919. [PubMed: 11906697]

Markou A, Koob GF. Construct validity of a self-stimulation threshold paradigm: effects of reward and performance manipulations. Physiol. Behav. 1992; 51:111-119. [PubMed: 1741436]

Mohler H, Fritschy JM. GABA $\mathrm{B}$ receptors make it to the top--as dimers. Trends Pharmacol. Sci. 1999; 20:87-89. [PubMed: 10203861]

Mombereau C, Kaupmann K, Froestl W, Sansig G, van der Putten H, Cryan JF. Genetic and pharmacological evidence of a role for $\mathrm{GABA}_{\mathrm{B}}$ receptors in the modulation of anxiety- and antidepressant-like behavior. Neuropsychopharmacology. 2004; 29:1050-1062. [PubMed: 15039762]

Mombereau C, Kaupmann K, Gassmann M, Bettler B, van der Putten H, Cryan JF. Altered anxiety and depression-related behaviour in mice lacking $\mathrm{GABA}_{\mathrm{B} 2}$ receptor subunits. Neuroreport. 2005; 16:307-310. [PubMed: 15706241]

Mondadori C, Jaekel J, Preiswerk G. CGP 36742: the first orally active GABA $B$ blocker improves the cognitive performance of mice, rats, and rhesus monkeys. Behav. Neural. Biol. 1993; 60:62-68. [PubMed: 8216160] 


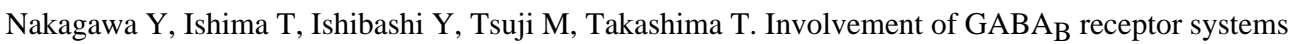
in action of antidepressants. II: Baclofen attenuates the effect of desipramine whereas muscimol has no effect in learned helplessness paradigm in rats. Brain Res. 1996a; 728:225-230. [PubMed: 8864486]

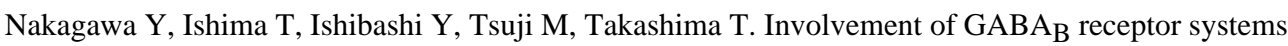
in experimental depression: baclofen but not bicuculline exacerbates helplessness in rats. Brain Res. 1996b; 741:240-245. [PubMed: 9001728]

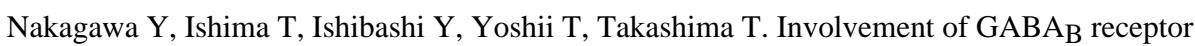
systems in action of antidepressants: baclofen but not bicuculline attenuates the effects of antidepressants on the forced swim test in rats. Brain Res. 1996c; 709:215-220. [PubMed: 8833757]

Nakagawa Y, Sasaki A, Takashima T. The $\mathrm{GABA}_{B}$ receptor antagonist CGP36742 improves learned helplessness in rats The $\mathrm{GABA}_{\mathrm{B}}$ receptor antagonist CGP36742 improves learned helplessness in rats. Eur. J. Pharmacol. 1999; 381:1-7. [PubMed: 10528127]

Nakagawa Y, Takashima T. The GABA B receptor antagonist CGP36742 attenuates the baclofen- and scopolamine-induced deficit in Morris water maze task in rats. Brain Res. 1997; 766:101-106. [PubMed: 9359592]

National Research Counsil. Guide for the Care and Use of Laboratory Animals. Washington, DC: National Academy Press; 1996.

Ng GY, Clark J, Coulombe N, Ethier N, Hebert TE, Sullivan R, Kargman S, Chateauneuf A, Tsukamoto N, McDonald T, Whiting P, Mezey E, Johnson MP, Liu Q, Kolakowski LF Jr, Evans JF, Bonner TI, O'Neill GP. Identification of a GABAB receptor subunit, gb2, required for

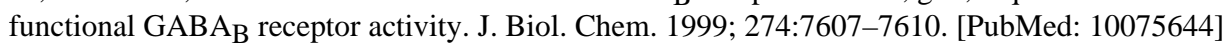

Nowak G, Partyka A, Palucha A, Szewczyk B, Wierońska JM, Dybala M, Metz M, Librowski T, Froestl W, Papp M, Pilc A. Antidepressant-like activity of CGP 36742 and CGP 51176, selective $\mathrm{GABA}_{\mathrm{B}}$ receptor antagonists, in rodents. Br. J. Pharmacol. 2006; 149:581-590. [PubMed: 16921399]

Paterson NE, Balfour DJ, Markou A. Chronic bupropion attenuated the anhedonic component of nicotine withdrawal in rats via inhibition of dopamine reuptake in the nucleus accumbens shell. Eur. J. Neurosci. 2007; 25:3099-3108. [PubMed: 17561823]

Paterson NE, Froestl W, Markou A. The GABA $\mathrm{B}$ receptor agonists baclofen and CGP44532 decreased nicotine self-administration in the rat. Psychopharmacology (Berl). 2004; 172:179-186. [PubMed: 14610636]

Paterson NE, Hanania T. The modified Geller-Seifter test in rats was insensitive to $\mathrm{GABA}_{\mathrm{B}}$ receptor modulation or blockade, or 5HT1A receptor activation. Behav. Brain Res. 2010; 208:258-264. [PubMed: 20006648]

Paterson NE, Semenova S, Markou A. The effects of chronic versus acute desipramine on nicotine withdrawal and nicotine self-administration in the rat. Psychopharmacology (Berl). 2008a; 198:351-362. [PubMed: 18438738]

Paterson NE, Vlachou S, Guery S, Kaupmann K, Froestl W, Markou A. Positive modulation of $\mathrm{GABA}_{\mathrm{B}}$ receptors decreased nicotine self-administration and counteracted nicotine-induced enhancement of brain reward function in rats. J. Pharmacol. Exp. Ther. 2008b; 326:306-314. [PubMed: 18445779]

Paxinos, G.; Watson, C. The Rat Brain in Stereotaxic Coordinates. 4th edition. San Diego: Academic Press; 1998.

Pilc A, Nowak G. GABAergic hypotheses of anxiety and depression: focus on $\mathrm{GABA}_{\mathrm{B}}$ receptors. Drugs Today (Barc). 2005; 41:755-766. [PubMed: 16395415]

Rylkova D, Boissoneault J, Isaac S, Prado M, Shah HP, Bruijnzeel AW. Effects of NPY and the specific Y1 receptor agonist [D-His(26)]-NPY on the deficit in brain reward function and somatic signs associated with nicotine withdrawal in rats. Neuropeptides. 2008; 42:215-227. [PubMed: 18468678]

Sahraei H, Etemadi L, Rostami P, Pourmotabbed A, Zarrindast MR, Shams J, Ghoshooni H, Noroozzadeh A, Esfandiari B, Salimi SH. GABA $B$ receptors within the ventral tegmental area are 
involved in the expression and acquisition of morphine-induced place preference in morphinesensitized rats. Pharmacol. Biochem. Behav. 2009; 91:409-416. [PubMed: 18789350]

Sanacora G, Fenton LR, Fasula MK, Rothman DL, Levin Y, Krystal JH, Mason GF. Cortical $\gamma$ aminobutyric acid concentrations in depressed patients receiving cognitive behavioral therapy. Biol. Psychiatry. 2006; 59:284-286. [PubMed: 16139814]

Sanacora G, Gueorguieva R, Epperson CN, Wu YT, Appel M, Rothman DL, Krystal JH, Mason GF. Subtype-specific alterations of $\gamma$-aminobutyric acid and glutamate in patients with major depression. Arch. Gen. Psychiatry. 2004; 61:705-713. [PubMed: 15237082]

Sanacora G, Saricicek A. GABAergic contributions to the pathophysiology of depression and the mechanism of antidepressant action. CNS Neurol. Disord. Drug Targets. 2007; 6:127-140. [PubMed: 17430150]

Schwenk J, Metz M, Zolles G, Turecek R, Fritzius T, Bildl W, Tarusawa E, Kulik A, Unger A, Ivankova K, Seddik R, Tiao JY, Rajalu M, Trojanova J, Rohde V, Gassmann M, Schulte U, Fakler $\mathrm{B}$, Bettler B. Native $\mathrm{GABA}_{\mathrm{B}}$ receptors are heteromultimers with a family of auxiliary subunits. Nature. 2010; 465:231-235. [PubMed: 20400944]

Semenova S, Markou A. The alpha2 adrenergic receptor antagonist idazoxan, but not the serotonin-2A receptor antagonist M100907, partially attenuated reward deficits associated with nicotine, but not amphetamine, withdrawal in rats. Eur. Neuropsychopharmacol. 2010; 20:731-746. [PubMed: 20627663]

Skjei KL, Markou A. Effects of repeated withdrawal episodes, nicotine dose, and duration of nicotine exposure on the severity and duration of nicotine withdrawal in rats. Psychopharmacology (Berl). 2003; 168:280-292. [PubMed: 12712232]

Slattery DA, Desrayaud S, Cryan JF. GABA $\mathrm{B}$ receptor antagonist-mediated antidepressant-like behavior is serotonin-dependent. J. Pharmacol. Exp. Ther. 2005; 312:290-296. [PubMed: 15333677]

Stoker AK, Semenova S, Markou A. Affective and somatic aspects of spontaneous and precipitated nicotine withdrawal in C57BL/6J and BALB/cByJ mice. Neuropharmacology. 2008; 54:12231232. [PubMed: 18452957]

Sufka KJ, Warnick JE, Pulaski CN, Slauson SR, Kim YB, Rimoldi JM. Antidepressant efficacy screening of novel targets in the chick anxiety-depression model. Behav. Pharmacol. 2009; 20:146-154. [PubMed: 19300238]

Urwyler S, Mosbacher J, Lingenhoehl K, Heid J, Hofstetter K, Froestl W, Bettler B, Kaupmann K.

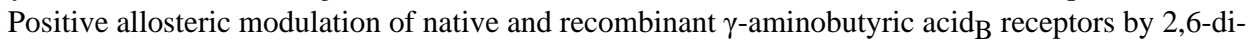
tert-butyl-4-(3-hydroxy-2,2-dimethyl-propyl)-phenol (CGP7930) and its aldehyde analog CGP13501. Mol. Pharmacol. 2001; 60:963-971. [PubMed: 11641424]

Urwyler S, Pozza MF, Lingenhoehl K, Mosbacher J, Lampert C, Froestl W, Koller M, Kaupmann K. $N, N$-Dicyclopentyl-2-methylsulfanyl-5-nitro-pyrimidine-4,6-diamine (GS39783) and structurally related compounds: novel allosteric enhancers of $\gamma$-aminobutyric acidB receptor function. $\mathrm{J}$. Pharmacol. Exp. Ther. 2003; 307:322-330. [PubMed: 12954816]

Vigot R, Barbieri S, Brauner-Osborne H, Turecek R, Shigemoto R, Zhang YP, Luján R, Jacobson LH, Biermann B, Fritschy JM, Vacher CM, Müller M, Sansig G, Guetg N, Cryan JF, Kaupmann K, Gassmann M, Oertner TG, Bettler B. Differential compartmentalization and distinct functions of GABA $_{B}$ receptor variants. Neuron. 2006; 50:589-601. [PubMed: 16701209]

Vlachou S, Markou A. GABA B receptors in reward processes. Adv. Pharmacol. 2010; 58:315-371. [PubMed: 20655488]

White JH, Wise A, Main MJ, Green A, Fraser NJ, Disney GH, Barnes AA, Emson P, Foord SM, Marshall FH. Heterodimerization is required for the formation of a functional $\mathrm{GABA}_{\mathrm{B}}$ receptor. Nature. 1998; 396:679-682. [PubMed: 9872316]

Xi ZX, Ramamoorthy S, Shen H, Lake R, Samuvel D, Kalivas PW. GABA transmission in the nucleus accumbens is altered after withdrawal from repeated cocaine. J. Neurosci. 2003; 23:3498-3505. [PubMed: 12716959] 


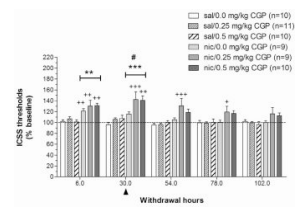

Figure 1. Effects of the GABA $B$ receptor agonist CGP44532 on ICSS thresholds during nicotine/ saline withdrawal

Data are expressed as the percentage of baseline thresholds obtained on the last day of pump exposure before removal of the minipump (mean \pm SEM). The arrowhead indicates the time-point (30 h post-pump removal) at which the $\mathrm{GABA}_{\mathrm{B}}$ receptor agonist CGP44532 was administered. Asterisks $(* * P<0.01, * * * P<0.001)$ indicate significantly elevated ICSS thresholds in nicotine-treated groups compared with the saline/0 mg/kg CGP44532-treated group. Plus signs $\left({ }^{++} P<0.01,{ }^{+++} P<0.001\right)$ indicate significant differences between each nicotine-treated group compared with its corresponding saline-treated group that received the same dose of CGP44532 (Newman-Keuls post hoc test). The pound sign $\left({ }^{\#} P<0.05\right)$ indicates a significant main effect of CGP44532 at the $30 \mathrm{~h}$ time-point. 


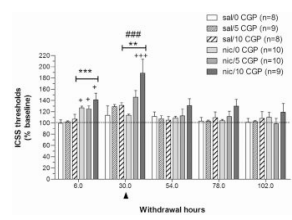

Figure 2. Effects of the GABA $A_{B}$ receptor antagonist CGP56433A on ICSS performance during nicotine/saline withdrawal

Data are expressed as the percentage of baseline thresholds obtained on the last day of pump exposure before removal of the minipump (mean \pm SEM). The arrowhead indicates the time-point ( $30 \mathrm{~h}$ post-pump removal) when the $\mathrm{GABA}_{\mathrm{B}}$ receptor antagonist CGP56433A was administered. Asterisks $(* * P<0.01, * * * P<0.001)$ indicate statistically significant elevations in ICSS thresholds in nicotine-treated groups compared with the saline $/ 0 \mathrm{mg} / \mathrm{kg}$ CGP56433A-treated group. Plus signs $\left({ }^{+} P<0.05,{ }^{++} P<0.001\right)$ indicate significant differences between each nicotine-treated group compared with its corresponding salinetreated group that received the same dose of CGP56433A and compared with the nicotine/ vehicle-treated group at the $30 \mathrm{~h}$ time-point (Newman-Keuls post hoc test). The pound signs (\#\#\# $P<0.01$ ) indicate a significant main effect of CGP44532 at the $30 \mathrm{~h}$ time-point. 


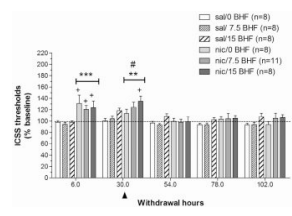

Figure 3. Effects of the $\mathrm{GABA}_{B}$ receptor positive modulator BHF177 on ICSS performance during nicotine/saline withdrawal

Data are expressed as the percentage of baseline thresholds obtained on the last day of pump exposure before removal of the minipump (mean \pm SEM). The arrowhead indicates the time-point (30 h post-pump removal) when the $\mathrm{GABA}_{\mathrm{B}}$ receptor positive modulator BHF177 was administered. Asterisks $(* * P<0.01, * * * P<0.001)$ indicate significantly elevated ICSS thresholds in nicotine-treated groups compared with the saline $/ 0 \mathrm{mg} / \mathrm{kg}$ BHF177-treated group. Plus signs $\left({ }^{+} P<0.05\right)$ indicate significant differences between each nicotine-treated group and its corresponding saline-treated group that received the same dose of BHF177 (Newman-Keuls post hoc test). The pound sign $\left({ }^{\#} P<0.05\right)$ indicates a significant main effect of BHF177. 